$\begin{gathered}\text { Egyptian Journal of Archaeological and Restoration Studies } \\ \text { An international peer-reviewed journal published bi-annually } \\ \text { www.ejars.sohag-univ.edu.eg }\end{gathered}$
EJARS

Original article

\title{
A CLOSER LOOK AT TWO 19TH CENTURY CHAMPLEVÉ AND PEINTURE ENAMEL TRAYS
}

\author{
Mohamed, W. ${ }^{1} \&$ Mohamed, N. ${ }^{2(*)}$ \\ ${ }^{1}$ Conservation dept, Faculty of Archaeology, Cairo Univ., Giza, Egypt. \\ ${ }^{2}$ Conservation dept, Assiut Sector, Ministry of Antiquities, Assiut, Egypt \\ E-mail address: niazymostafa_re@yahoo.com
}

\begin{tabular}{|c|c|}
\hline Article info. & EJARS - Vol. 11 (2) - Dec. 2021: 185-192 \\
\hline Article history: & Abstract: \\
\hline Received: 23-4-2021 & This research aims to investigate two treasured artifacts from the \\
\hline Accepted: 8-11-2021 & $19^{\text {th }}$ century museum's collections in Cairo, Egypt. The first is an \\
\hline Doi: $10.21608 /$ ejars.2021.210369 & $\begin{array}{l}\text { Indian Mughal enameled gilded silver tray from Aljazera Museum } \\
\text { and the second is an Ottoman enameled gilded silver tray from the } \\
\text { Faculty of Applied Arts' Museum. The trays showed two sophisticated } \\
\text { methods of enameling: champlevé and peinture. Multiple colour } \\
\text { tones of opaque and transparent enamels were used. To identify } \\
\text { them different analytical techniques were utilized, Portable X-ray } \\
\text { fluorescence (pXRF) and scanning electron microscopy with energy } \\
\text { dispersive } x \text {-ray spectroscopy (SEM-EDX). Results proved that the }\end{array}$ \\
\hline Keywords: & metal substrate in both trays is silver-copper alloy. Gold residues \\
\hline Gilded silver & $\begin{array}{l}\text { were found on the obverse and some other areas. The enamel } \\
\text { contains the essential components of the vitreous material e.q. }\end{array}$ \\
\hline Champlevé & silica, soda, potassium oxide, calcium oxide and lead oxide with \\
\hline Peinture & little to minute amounts of cobalt oxide, copper oxide, zinc oxide \\
\hline Trays & and iron oxide which are responsible for the colour tones, while lead \\
\hline$p X R F, E D X$ & $\begin{array}{l}\text { arsenate is responsible for the opacity. The chemical composition } \\
\text { of enamel material confirmed their origin and date. }\end{array}$ \\
\hline
\end{tabular}

\section{Introduction}

The art of enameling metals is the process of applying enamel powder onto the metal surface, then firing at high temperature, for the purpose of decoration $[1,2]$. This art has been known since the early civilizations around the Mediterranean. In the $6^{\text {th }}$ century B.C. or even earlier it has been practiced by the Egyptian, Phoenicians, Assyrians, Greeks, Romans, and Etruscans [3,4]. The enamel work has reached a great degree of perfection in cloisonné' at Greek sculpture in the fifth century B.C. By the $3^{\text {rd }}$ century B.C., the enamel process had spread to England and Ireland. The process continued to move slowly from Europe to Asia
Minor and from the Middle East to India and China, and then to Japan by the $3^{\text {rd }}$ century A.D. [5]. Enameling on metals is most successfully practiced in India [6], In spite of that, there is no mention of enameling in early Indian texts before the $15^{\text {th }}$ century. The only available reference found on this subject is in the Ain-i-Akbari written in the $16^{\text {th }}$ century by Abu'l Fazl, during the reign of the Mughal Emperor Akbar. The meenakar or enameller used to work on cups, flagons, rings and other articles in gold and silver [7]. By the end of the $14^{\text {th }}$ century, this technique was also widespread in Spain and Iran [8]. The 
enamel can sometimes be melted directly on the metal, but more often into a depressions or cells prepared to receive it [3]. The metal can be gold, silver, copper, bronze, or steel [9]. The enamel is a vitreous glaze of finely ground glass. The material is produced from a mixture of silica, alkali compounds, which lower the melting temperature, lead oxides, salts of soda, potassium, boric oxides, and various metallic oxides. It can be, transparent, translucent or opaque $[4,10]$. There is a number of enamel application methods; champlevé, cloisonné peinture, etc. [11]. *) Champlevé is one of the oldest application methods [12], in which the enamel is laid into a depression made by carving, etching, stamping, piercing, or soldering to a background [13, 14]. *) Peinture enamel, it is a style in which a picture can be built up using successive firing [15]. It gains its outline from the colour scheme [16], then heated to a high temperature until the enamel melts and fuses to the metal [17]. *) Cloisonné enamel is produced by setting up cells or cloisons on the surface of the object or material to be decorated. This is done by bending wire into the required shapes then soldering these wire units onto the metal surface which forms the background. The wire thus forms cells into which the enamel is placed and then melted or fused in the furnace [13].

\subsection{The Indian Mughal tray}

This object is a circular champlevé enameled tray with $20.4 \mathrm{~cm}$ diameter and a raised rim, fig. (1-a, b). It is exhibited in Aljazera Museum in Cairo, Egypt with the artifact collection accession number 72. It was made in the city of Hyderabad in India during the $19^{\text {th }}$ century. The decorations take the form of two concentric circles; the inner circle is wide with a floral central pattern, surrounded by eight large petals containing alternating stylized trees patterns. The outer circle is outlining a narrow register of vegetal scroll. The decorations are executed in green, blue and turquoise enamels.

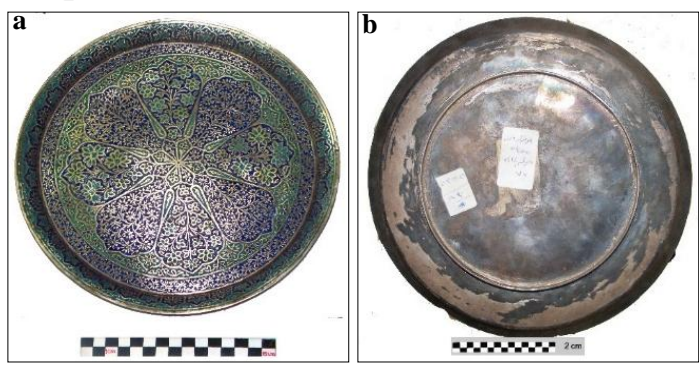

Figure (1) Shows $\underline{\mathbf{a}}$. the front side, $\underline{\mathbf{b}}$. the back side of the Indian Mughal tray

\subsection{The Ottoman tray}

This colourful Ottoman tray is exhibited in the Museum of the Faculty of Applied Arts at Helwan University, Egypt. The artifact collection accession number is 93/5. It incorporates two methods of enameling: champlevé and peinture enamel and dates back to the era of Sultan Abdul Hamid II 12931327 AH./1876-1909 AD., fig. (2-a, b). The tray is rectangular in shape with $31 \mathrm{~cm}$ length and $23.5 \mathrm{~cm}$ width. The circular tuğra ornamented pattern is $13.5 \mathrm{~cm}$ diameter. The tray bears the most outstanding symbol of the Ottoman sultan's authority, tuğra (cipher), which was affixed to all official documents, it was also carved on seals and stamped on coins and metal objects. The tuğra mark of the Sultan could be used meanwhile as a silver hallmark [18,19]. The tray is decorated with tuğra which was painted in an oval central area around which, thin silver lines slanting to the left and right forming lozenges adorned with green, red and turquoise enamels. In the corners four bouquets of pink and blue flowers were painted on a white ground.

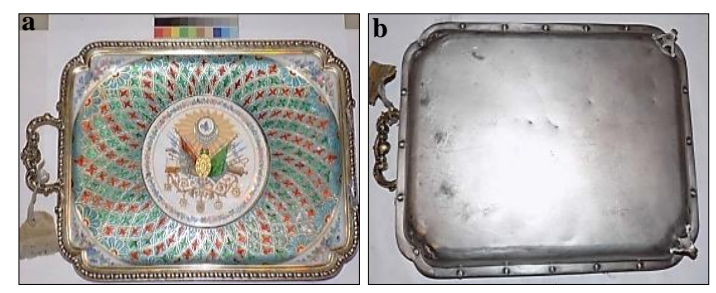

Figure (2) Shows a a. the front side, $\underline{\mathbf{b}}$. the back side of the Ottoman tray 


\section{Materials and Methods}

\subsection{Sampling}

All enamel colours and their corresponding codes, tab. (1-a, b) were sampled after removing any attached dirt and stains using cotton swabs to ensure accurate analysis results.

Table (1-a) Enamel colours of the Indian Mughal tray and the corresponding codes

\begin{tabular}{ccc}
\hline $\begin{array}{c}\text { Enamel colour of } \\
\text { Indian Mughal tray }\end{array}$ & Enamel colour codes \\
\hline Green & 2340 Glass green \\
Turquoise & 2420 See green \\
Blue & (A) & \\
\hline
\end{tabular}

Table (1-b) Enamel colours of the Ottoman tray and the corresponding codes

\begin{tabular}{|c|c|}
\hline $\begin{array}{c}\text { Enamel colours of } \\
\text { Ottoman tray }\end{array}$ & Enamel colour codes \\
\hline Green & $\begin{array}{r}2320 \text { Spring } \\
\text { Green }\end{array}$ \\
\hline Turquoise & $\begin{array}{r}2510 \text { Cascade } \\
\text { Blue }(\mathrm{A})\end{array}$ \\
\hline White & $\begin{array}{r}1030 \text { Foundation } \\
\text { White }\end{array}$ \\
\hline Red & $\begin{array}{r}2800 \text { Opalescent } \\
\text { Red }\end{array}$ \\
\hline
\end{tabular}

\subsection{Portable x-ray fluorescence}

The metal substrate of the trays were analyzed using Portable X-ray fluorescence (pXRF) Model NITON/ XLt 8138 (USA), with software version 4.2E.

\subsection{Scanning electron microscope coupled with EDX}

The enamels were identified and analyzed with SEM-EDX (Quanta 250 FEG attached to EDX Unit, FEI Company, Netherlands) with accelerating voltage $30 \mathrm{~V}$. The samples were analyzed without coating at low vacuum.

\section{Results}

\subsection{Identification of the metal sub- strate}

The analysis results of the Indian Mughal tray shown in fig. (3-a) indicate that the metal substrate is an $\mathrm{Ag}-\mathrm{Cu}$ alloy. As the tray reverse side is clear and free from enamel decorations, $(\mathrm{Ag})$ content was very high (94.14 wt. \%) while $\mathrm{Cu}$ was (4.99 wt. $\%)$. The ornamented obverse side of the tray gives different results; Ag (63.35 wt. $\%), \mathrm{Cu}(4.63$ wt. \%) and $\mathrm{Au}(7.27$ wt. \%). The presence of $(\mathrm{Au})$ indicates gilding of the enameled obverse, whereas the reverse side is free of gold. pXRF analysis results of the Ottoman tray are given in fig. (3-b). They proved that the reverse side, the handles, the outer frame and the legs, are made of $\mathrm{Ag}-\mathrm{Cu}$ alloy. $\mathrm{Ag}$ content in the reverse side reached $(95.38 \mathrm{wt}$. \%) with a small amount of $\mathrm{Cu}$ (3.27 wt. \%). The outer frame and the handles analysis results indicated a noticeable amount of $\mathrm{Au}$ (12.84 \% and 10.42 wt. \%).

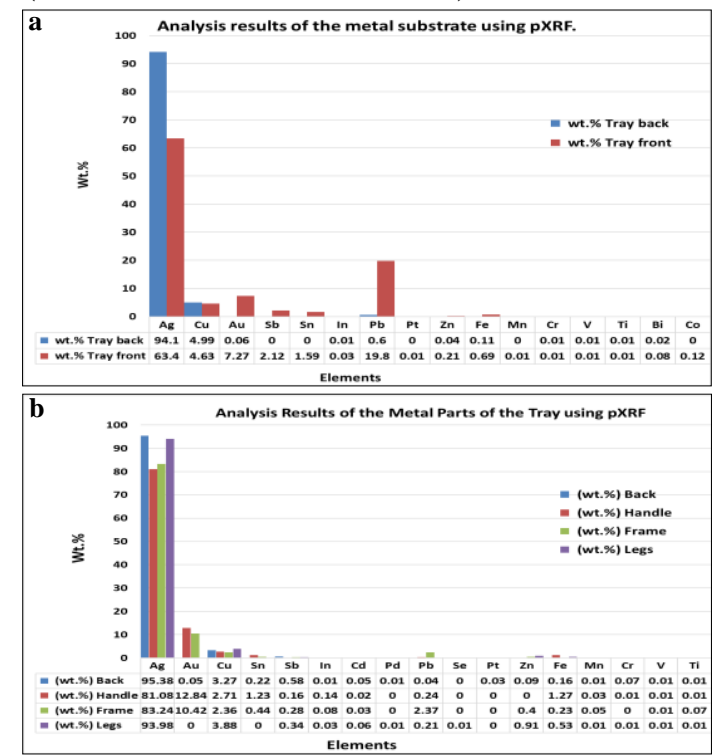

Figure (3) Shows pXRF analytical results of the metal substrate of $\underline{\mathbf{a}}$. the Indian Mughal tray, $\underline{\mathbf{b}}$. the Ottoman tray

\subsection{Identification of enamel colours palette:}

EDX analysis results of green, blue and turquoise enamel samples of the Indian $\mathrm{Mu}-$ ghal tray, fig. (4). 


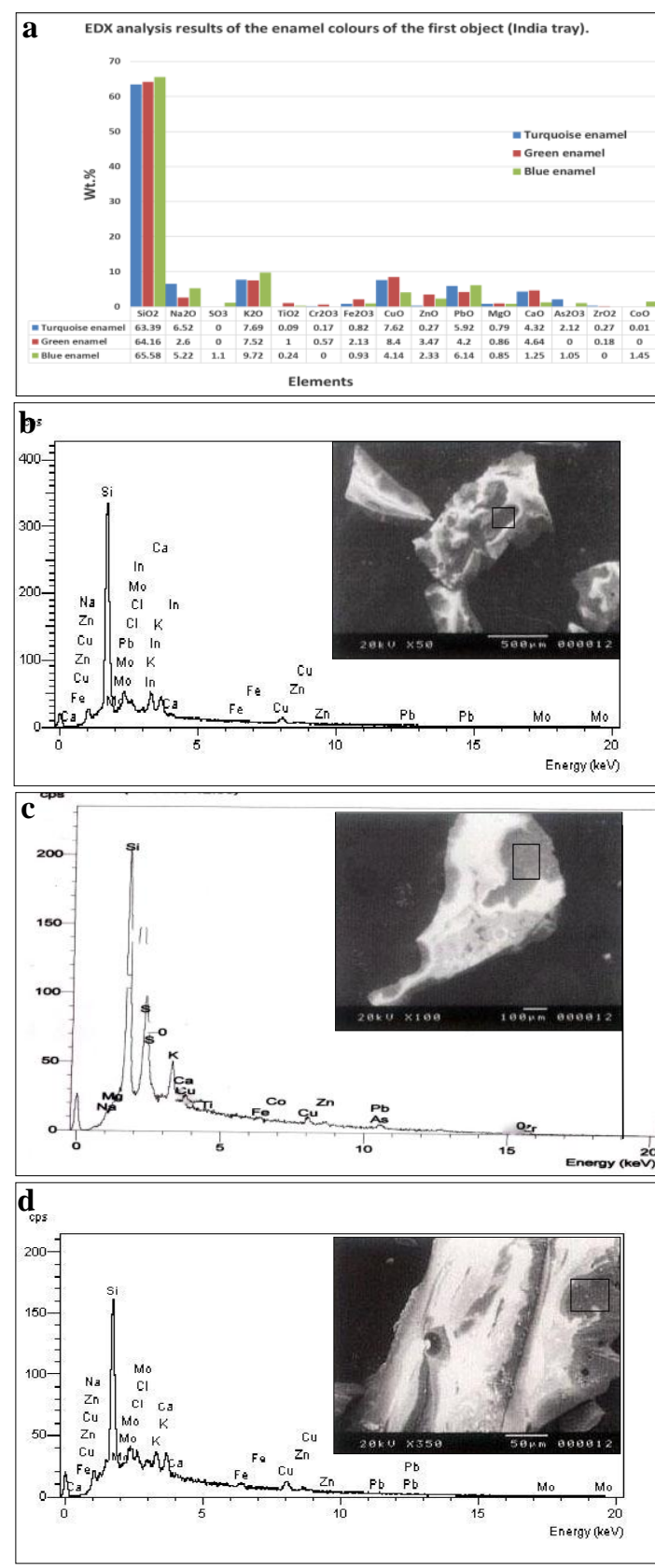

Figure (4) Shows a. EDX analytical results of the enamel colours of the Indian Mughal tray, EDX spectrum of the $\underline{\mathbf{b}}$. green enamel, c. blue enamel, $\underline{\text { d. }}$ turquoise enamel.

Generally, the enamels contain ( $\mathrm{Si}, \mathrm{Pb}, \mathrm{K}$ and $\mathrm{Na}$ ), in addition to colouring metal oxides. These results indicated that the green enamel consists of $\mathrm{SiO}_{2},(64.16 \%)$, $\mathrm{K}_{2} \mathrm{O}(7.52 \%), \mathrm{Na}_{2} \mathrm{O}(2.6 \%), \mathrm{CaO}(7.64 \%)$, $\mathrm{PbO}(4.20 \%)$, and $\mathrm{CuO}(4.64 \%)$, and small amounts of $\mathrm{Fe}_{2} \mathrm{O}_{3}(2.13 \%)$ which in combi- nation with $\mathrm{CuO}$ result in the green colour, fig. (4-a). Blue enamel consists of $\mathrm{SiO}_{2}$, (65.58 \%), $\mathrm{K}_{2} \mathrm{O}(9.72 \%), \mathrm{Na}_{2} \mathrm{O}(5.22 \%)$, $\mathrm{CaO}$ (1.25\%), $\mathrm{PbO}$ (6.14\%), $\mathrm{CuO}(4.14 \%)$, and small amounts of $\mathrm{CoO}(1.45 \%)$ as blue enamel is referred to $\mathrm{CoO}$, fig. (4-b). Turquoise enamel consists of $\mathrm{SiO}_{2},(63.39 \%)$, $\mathrm{K}_{2} \mathrm{O}$ (7.69\%), $\mathrm{Na}_{2} \mathrm{O}$ (6.52\%), $\mathrm{CaO}$ (4.32\%), $\mathrm{PbO}(5.92 \%), \mathrm{CuO}(7.62 \%)$, and small amounts of $\mathrm{As}_{2} \mathrm{O}_{3}$ (2.12\%), fig. (4-c). Turquoise colour was obtained by adding higher concentration of copper oxide $(\mathrm{CuO})$ in alkalibased glass (high percentage of $\mathrm{K}_{2} \mathrm{O}$ and $\mathrm{Na}_{2} \mathrm{O}$ ). On the other hand, EDX analytical results of green, turquoise, red and white enamels of the Ottoman tray, fig. $(5 \& 6)$ proved that the enamel contain significant amounts of $(\mathrm{Si})$ and $\mathrm{PbO}$ with little amount of alkalis oxides, of ( $\mathrm{Na}$ and $\mathrm{K}$ ) in addition to traces of ( $\mathrm{Al}, \mathrm{Mg}$ and $\mathrm{Ca}$ ) oxides. These results indicated that the green enamel consists of $\mathrm{SiO}_{2},(52.85 \%), \mathrm{K}_{2} \mathrm{O}(8.47 \%)$, $\mathrm{Na}_{2} \mathrm{O}$ (3.39\%), $\mathrm{CaO}$ (0.89\%), PbO (29. $43 \%)$, and $\mathrm{CuO}(3.67 \%)$, the copper again is responsible for the green enamel, fig. (6-a). Turquoise enamel consists of $\mathrm{SiO}_{2}$ (46.51\%), $\mathrm{K}_{2} \mathrm{O}$ (11\%), $\mathrm{Na}_{2} \mathrm{O}(3.30 \%), \mathrm{PbO}$ (23.31\%), and $\mathrm{CuO}(3.57 \%)$, Turquoise enamel contained copper oxide in addition to high percentages of potassium and sodium oxides to obtain turquoise colour, fig. (6-b). EDX analysis results of Opaque white enamel contained essential components of enamel, $\mathrm{SiO}_{2},(49.51 \%), \mathrm{K}_{2} \mathrm{O}$ (7.86\%), $\mathrm{Na}_{2} \mathrm{O}$ (2.51\%), $\mathrm{PbO}(34.5 \%)$, and small amounts of $\mathrm{As}_{2} \mathrm{O}_{3}(1.21 \%)$, the presences of the arsenic (As) in the form of arsenic trioxide $\left(\mathrm{As}_{2} \mathrm{O}_{3}\right)$ is an opacifying agent to obtain the opaque white colour, fig. (6-c). EDX analysis results of red enamel contained also the essential components of enamel, $\mathrm{SiO}_{2}(51.54 \%), \mathrm{K}_{2} \mathrm{O}(6.25 \%)$, $\mathrm{Na}_{2} \mathrm{O}$ (3.68\%), $\mathrm{PbO}$ (38.53\%). Surprisingly, the red enamel analysis results indicated the absence of colouring agents (6-d). Finally, closer microscopic examination revealed the presence of a gold layer beneath the transparent colourless vitreous enamel, fig. (7). 


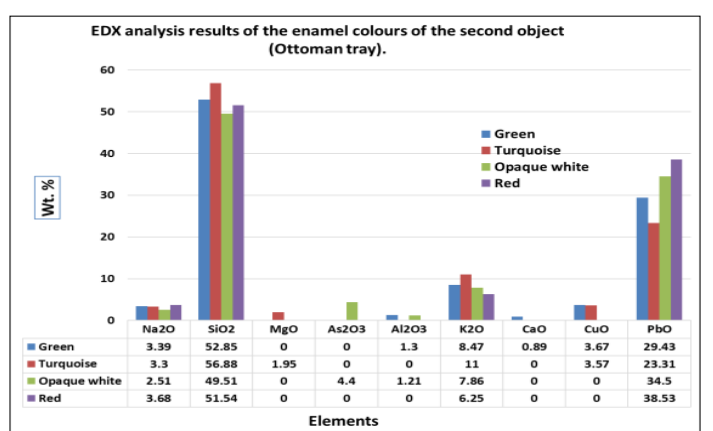

Figure (5) Shows EDX analytical results of the enamel colours of the Ottoman tray.
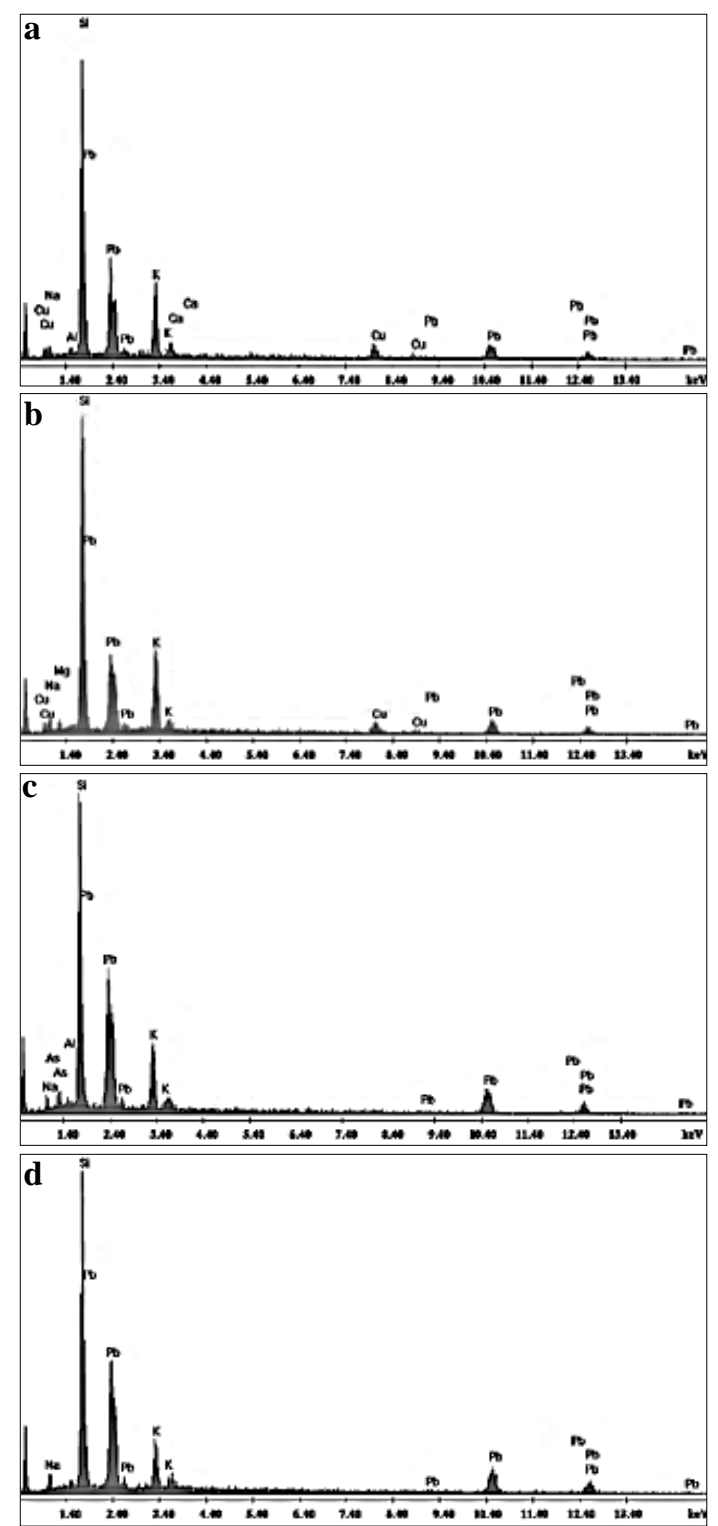

Figure (6) Shows EDX spectrum of the enamel colours of the Ottoman tray, $\underline{\text { a. }}$ green enamel, $\underline{\mathbf{b}}$. turquoise enamel, $\underline{\mathbf{c}}$. white enamel, $\mathbf{\mathbf { d }}$. red enamel

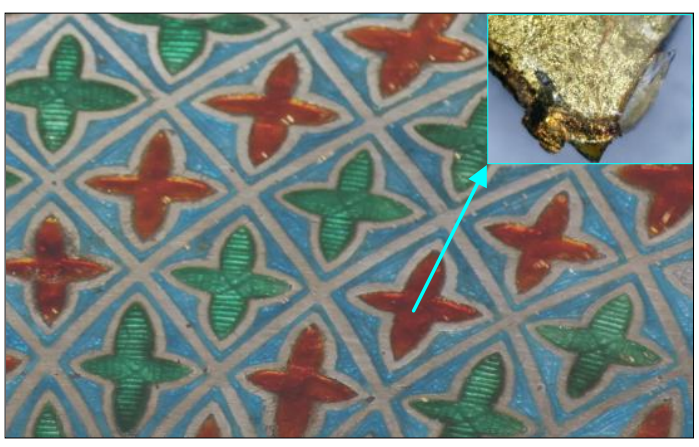

Figure (7) Shows digital microscope photomicrograph of the gilding layer beneath the enamel layer of the Ottoman tray.

\section{Discussion}

pXRF analysis of the metal's substrate showed that the metal component of both trays is a silver alloy that contains a percentage of copper, it is called the binary (silver-copper alloy). The presence of gold indicates selective gilding of the objects. Pure silver is normally considered too soft to be used for manufacturing household or even decorative items [17]. So, the addition of copper in $\mathrm{Ag}-\mathrm{Cu}$ alloys considerably increases the strength, hardness, and wearresistance of silver without leaving a deleterious effect on its ductility and formability [20]. This made the alloy a perfect choice for manufacturing the trays. The selective gilded areas in both trays could indicate the application of fire gilding to give the impression of sound gold parts or for creating a fascinating appearance [21]. EDX analysis results of enamel colours indicated that the enamels used by the enamellists in both trays primarily composed of silicon $(\mathrm{Si})$, lead $(\mathrm{Pb})$, potassium $(\mathrm{K})$ and sodium $(\mathrm{Na})$, in addition to some other distinctive elements of each colour. The enamel that is used by the enamellist is primarily glass technically called silica to provide special properties such as luster, fusibility, and elasticity [22], silica that occurs in nature as quartz (flint, sandstone) is basically silicon dioxide [1,23] Among the components of the enamel adding alkali such as potassium and sodium in form of oxides which are 
used in the manufactures of the enamel. The bright, polished, sparkling effect of enamels is partly due to potash, while the presence of soda renders the enamel more elastic [24]. Lead oxide is the ideal material for lower temperatures since it possesses the highest refractive index and confers the greatest brilliance [23]. Softness and hardness of enamel are determined by the amount of lead oxide. The lower lead oxide content produces the harder enamel. The harder the enamel the greater the quantity of silica contained in it, and the greater the resistance to atmospheric or chemical action; On the contrary, the softer the enamel the greater its percentage of lead, and the more liability to decompose by atmospheric influences and chemical factors $[24,25]$. Even though lead became an almost universal additive to enamels by the $19^{\text {th }}$ century [26]. From the obtained analysis results we can conclude that copper oxide in the form of cupric oxide $(\mathrm{CuO})$ is responsible for green enamel colour in both trays [27]. The Blue colour is usually obtained by dissolving $\left(\mathrm{Co}^{+2}\right.$ ions) within the glass silicate network [28]. Small amounts of zinc and arsenic were also found in the enamel. These elements are appearing to be associated with the origin of the cobalt ore used to make this enamel [29]. The results confirmed also that turquoise enamel was achieved by the presence of copper ions together with a high alkali medium (\%10-12 $\left.\mathrm{K}_{2} \mathrm{O}+\mathrm{Na}_{2} \mathrm{O}\right)$ in addition to a high content of lead oxide $\mathrm{PbO}[28$, 30,31]. As for the white enamel, lead arsenate was used as an opacifier. It was introduced around 1750 A.D. and became the most common opacifying agent in the $19^{\text {th }}$ century, causing the distinguished $\mathrm{As}_{2} \mathrm{O}_{3}$ content of $19^{\text {th }}$ century opaque enamels [32]. For the red enamel we found that the red enamel is nothing, but a transparent enamel melted over a layer of gold, once fused over the foil it gives greater brilliance and protection [12]. This is an early practice of decoration with enamel in which, a layer of silver or gold foil is applied beneath the enamel layer. These results agree with the findings of Mohamed, 2011 [26], that the enamel can be applied on gold foil of about 20 carats in ornamental objects. A relatively high lead concentration $(20 \%)$ was found in the transparent enamel. This result is in agreement with the assumption that lead potash glass was used for the painted enamel [26]. This can indisputably be assigned to the $19^{\text {th }}$ century production [32]. The use of arsenic in the form of oxide to obtain opaque white enamel was commonly used during the $19^{\text {th }}$ century. In conclusion, it was found that there is a great similarity in the chemical composition of the metal substrate and the enamel in both trays. The alloy is a high $\mathrm{Ag}-\mathrm{Cu}$, in close proximity to the wellknown Britannia alloy. As for the enamel, they are all made of lead vitreous enamel, in addition to the use of transparent enamel colours, champlevé enamel and partial and selective gilding. Nevertheless, the Ottoman tray has extraordinary combination between champleve' and peinture enamel, with more colourful palette, more degrees of opaque enamel in addition to the application of colourless enamel on gold foil to add a mixture of interference and colour reflection. Despite the differences of origin, culture and methods of enamelling, art goes beyond boundaries.

\section{Conclusion}

In this research two colourful trays were analytically investigated; an Indian Mughal enameled gilded silver tray and an Ottoman enameled gilded silver tray. They were decorated by champlevé and peinture enamel. The $p X R F$ and SEM-EDX analysis results proved that the metal substrate alloy is $\mathrm{Ag}-\mathrm{Cu}$ and gilding was applied on some selected areas. The enamel contains ( $\mathrm{Si}, \mathrm{K}, \mathrm{Na}$, and $\mathrm{Pb}$ ) with little amounts of colouring agents, (Co, $\mathrm{Cu}, \mathrm{Zn}$ and $\mathrm{Fe}$ ). The presence of high 
lead content in the enamel colours and arsenic in white enamel agreed with the proposed date and origin of the trays.

\section{References}

[1]Matthews, G. (1984). Enamels, enameling, enamellists, Chilton Book Co., Pennsylvania.

[2]Wiener, L. (1948). Handmade jewelry: A manual of techniques, D. Van Nostrand Co, Inc., NY.

[3] Arthur, F. \& Payne, B. (1914). Art metal work with inexpensive equipment, The Manual Arts Press Peoria, Illinois.

[4]Grath, J. (1994). First steps in enamelling, The Apple Press, Singapore.

[5]Kuemmerlein, K. (2004). Arts \& Communication, metal enameling, Wisconsin 4-H 158 Pub., Univ. of Wisconsin, USA.

[6] Wigley, T. \& Stansbie, J., (1911). The Art of the Goldsmith and Jeweller: A Treatise on the Manipulation of Gold in the Various Processes of Goldsmith's Work, and the Manufacture of Personal Ornaments, \&c, \&c, for the Use of Students and Practical Men, Charles Griffin and Co. Ltd., London.

[7]Hunter, A. (1876). Enamelling on precious metals in India, The Art $J$. (1875-1887), Vol. 2, pp. 73-75.

[8]Rossi, S., Russo, F., \& Compagnoni, A. (2020). A brief history of porcelain enamel: From artistic enamel to technical enamelling, https://encyclopedia. pub/revision/11460/v1 (20-3- 2021).

[9]Maryon, H. (1971). Metalwork and enameling, Dover Pub., Inc., NY.

[10] Chamberlain, M. (1976). Metal jewelry techniques, Watson-Guptill Pub., NY.

[11] Rose, A. \& Cirino, A. (1967). Jewelry making and design: An illustrated textbook for teachers, students of design and craft workers, $4^{\text {th }}$ ed., Dover Pub. Inc., NY.

[12] Dipasquale, D., Delius, J \& Eckersley, T. (1975). Jewelry Making: An illustrated guide to technique, $1^{\text {st }}$ ed., Prentice-Hall, Inc., New Jersey.
[13] Hawkins, L. (1973). Art metal and enameling, Chos. A. Bennett CO., Inc. USA.

[14] Pack, G. (1961). Jewelry and enameling, $3^{\text {rd }}$ ed. Van Nostrand, NY.

[15] Marsh, D. (1979). Jewellery, The MacMillan Press LTD, London.

[16] Davidson, P. (1913). Educational metal craft: A practical treatise on repoussé, fine chasing, silver smithing, jewellery, and enamelling. Specially adapted to meet the requirements of the instructor, the student and the apprentice, Longman, Green \& Co., NY.

[17] Davran, A. (2011). Enameling application, on metals from past to future, M.Sc., Design Studies dept., İzmir Univ. of Economics, Turkey.

[18] Kouymjian, D. (2003). Review of Garo Kürkman, Ottoman silver marks, (Istanbul: Mathusalem Publications, 1996), J. of the Society for Armenian Studies, Vol. 12, pp. 86-88,

[19] Online Encyclopedia of Silver Marks, Hallmarks, \& Makers' Marks, http:// www.925-1000.com/foreign_marks3. html, (20-3-2021)

[20] Al-Saad, Z. \& Bani Hani, M. (2007). Corrosion behavior and preservation for saving our cultural heritage, in: Vasilike, A. (ed.) Int. Conf. on Strategies for Saving Indoor Metallic Collections with a Satellite Meeting on Legal Issues in the Conservation of Cultural Heritage, TEI, Athens, pp. 177-183.

[21] Ingo, G., Padeletti, G., De Caro, T., et al. (2007). Micro chemical investigation of ancient silver- and gold-plated objects: Coating techniques and degradation mechanisms, strategies for saving our cultural heritage, in: Vasilike, A. (ed.) Int. Conf. on Strategies for Saving Indoor Metallic Collections with a Satellite Meeting on Legal Issues in the Conservation of Cultural Heritage, TEI, Athens, pp. 9- 13. 
[22] Taylor, L. (1977). Copper enameling, A.S. Barnes and company, NY.

[23] Winter, E. (1970). Enamel painting techniques, Elsevier Pub., England.

[24] Bates, K. (1951). Enameling principles and practice, The World Publishing Company, New York.

[25] Fisher, A. (1906). The art of enamelling upon metal with a short appendix concerning miniature painting on enamel, Forgotten Books, London

[26] Mohamed, W. (2011). Scientific study and conservation of a painted enamel Qajar Pendant, e-Conservation, Vol. 19, pp. 70-78.

[27] Heck, M. \& Hoffmannn, P. (2000). Coloured opaque glass beads of the Merovingians, Archaeometry, Vol. 42, (2), pp. 341-357.

[28] Kırmızı, B., Colomban, P. \& Quetteb, B. (2010). On-site analysis of Chinese
Cloisonne' enamels from fifteenth to nineteenth centuries, J. Raman Spectroscope, Vol. 41, pp. 780-790.

[29] Wypyski, M. (2000). Technical appendix: Compositions of enamels on the George watch, Metropolitan Museum Journal, Vol. 35, pp. 150-152.

[30] Day, L. (1907). Enameling, a comparative account of the development and practice of the art $\mathrm{B}$. T. Batsford, London.

[31] Mohamed, W. \& Mostafa, N., (2017). Testing coatings for enameled metal artifacts, IJCS, Vol. 8 (1), pp. 15-24.

[32] Van der Linden, V., Olivier, S., Jos, H., et al. (2010). Chemical analysis of $16^{\text {th }}$ to $19^{\text {th }}$ century Limoges School 'painted enamel' objects in three museums of the Low Countries, X-Ray Spectrum, Vol. 39, pp. 112-121. 